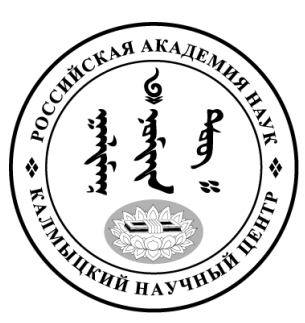

Published in the Russian Federation

Oriental Studies (Previous Name: Bulletin of the Kalmyk Institute for

Humanities of the Russian Academy of Sciences)

Has been issued as a journal since 2008

ISSN: 2619-0990; E-ISSN: 2619-1008

Is. 4, pp. 691-707, 2019

DOI: 10.22162/2619-0990-2019-44-4-691-706

Journal homepage: https://kigiran.elpub.ru

УДК 881.512 .156

\title{
Числительные в топонимах Тувы
}

\author{
Кара-оол Любовь Салчаковна ${ }^{1}$ \\ ${ }^{1}$ Тувинский государственный университет (д. 36, ул. Ленина, 667000 Кызыл, Российская Феде- \\ рация) \\ кандидат филологических наук, доцент \\ ORCID: 0000-0001-9270-2912. E-mail: 1karaool61@mail.ru
}

Аннотация. Введение. Как для топонимов любого региона, географическая среда является первичной основой, на которой развились топонимы Тувы, но в данной статье автор изучает топонимы с иной семантикой, поэтому основной цзелью данного исследования является анализ топонимов с числительными, с уточнением лексического значения и этимологии его компонентов, вторичности или первичности возникновения топонимических метонимий, ареала распространения некоторых странствующих тюркских географических названий среди топонимов Тувы. $M a-$ териалом для статьи послужили полевые материалы автора, собранные во время комплексных и диалектологических экспедиций с 1999 по 2018 годы, а также примеры, извлеченные из «Топонимического словаря Тувы» Б. К. Ондар. Результатыл. На основе проведенного исследования автор приходит к выводу, что топонимах с числительными количественный показатель а) точно определяет число географических объектов, б) передает значение 'несколько', в) передает значение 'много', д) с неясным количественным показателем. В качестве первого компонента сложных топонимов выступают общетюркские числительные, за исключением сая 'миллион', который заимствован из тибетского посредством монгольского языка, а вторыми компонентами являются общетюркские названия географических объектов, деревьев, а также незначительное число монголизмов или тюрко-монгольских слов, относящиеся к другим лексическим группам слов. Среди топонимов Тувы с числительными зафиксированы несколько странствующих тюркских географических названий, ареалом распространения которых являются Горный Алтай, Казахстан, Киргизия, Хакассия и Кавказские Минеральные Воды.

Ключевые слова: топонимы, числительные, значение, компоненты, тувинский язык, общетюркские лексемы, тюрко-монгольские лексемы, монголизмы

Благодарность. Исследование выполнено при финансовой поддержке РФФИ в рамках научного проекта № 19-012-00073 («Трансформационные процессы в ономастике народов Центральной Азии: история и современность (на примере Тувы, Тофаларии, Калмыкии и Монголии»).

Для цитирования. Кара-оол Л. С. Числительные в топонимах Тувы. Oriental Studies. 2019; (4): 691-706. DOI: 10.22162/2619-0990-2019-44-4-691-706. 
UDC 881.512.156

\title{
Numerals in Toponyms of Tuva
}

\author{
Liubov S. Kara-ool \\ ${ }^{1}$ Tuvan State University (36, Lenin St., 667000 Kyzyl, Russian Federation) \\ Cand. Sc. (Philology), Associate Professor \\ ORCID: 0000-0001-9270-2912.E-mail: 1karaool61@mail.ru
}

\begin{abstract}
Introduction. When it comes to Tuvan toponymy it is, as usual, the geographical environment that served as the primary basis for its development, but this article studies place-names with different semantics. Goals. The paper basically aims to analyze place-names containing numerals, clarify lexical meanings and etymologies of their components, identify some secondary or primary nature of the emerged toponymic metonymies, delineate the distribution area of some 'wandering' Turkic geographical names among Tuva's toponyms, and ascertain the history of their emergence. Materials. The article examines the author's field data collected during comprehensive research expeditions undertaken between 1999 and 2018, as well as examples extracted from The Toponymic Dictionary of Tuva by B. K. Ondar. Results. The study concludes that in numerals-containing toponyms the quantitative element - a) accurately specifies the number of geographical objects; b) expresses the meaning 'several'; c) expresses the meaning 'a lot'; e) and acts as an unclear quantitative indicator. First components of complex toponyms are usually common Turkic numerals, the exception to this being saya 'million' borrowed from Tibetan through Mongolian, while latter components are common Turkic names of geographical objects, trees, including a small number of Mongolisms or TurkoMongolisms related to other lexical clusters. Tuva's numerals-containing place-names comprise a number of 'wandering' Turkic geographical names to be traced throughout the Altai, Kazakhstan, Kyrgyzstan, Khakassia, and the Caucasian Mineral Waters.

Keywords: place names, numerals, meaning, components, Tuvan language, common Turkic lexemes, Turko-Mongolic lexemes, Mongolisms

Acknowledgements: The reported study was funded by RFBR, project number 19-012-00073 ('Transformation Processes in Onomastics of the Peoples of Central Asia: History and Modernity (on the Example of Tuva, Tofalaria, Kalmykia and Mongolia)').

For citation: Kara-ool L. Numerals in Toponyms of Tuva. Oriental Studies. 2019; (4): 691-706. DOI: $10.22162 / 2619-0990-44-4-691-706$.
\end{abstract}

\section{है}

\section{Введение}

Топонимы в тувинском языке, как и в других языках, относятся к древним пластам лексики тувинского языка и отражают географические и биологические особенности Тувы, богатую историю, материальную и духовную культуру тувинского народа, а также лексические особенности языка.

Из истории изучения топонимии в тувинском языке. Топонимы Тувы впервые зафиксированы в орхоно-енисейских памятниках [Кормушин 1997; Кормушин 2008]; многие географические объекты отмечены в картах русских путешественников Л. Э. Шварца [Шварц 1864],
Н. Ф. Веселкова [Веселков 1871] и др.; зафиксированы в неоценимых материалах экспедиций Г. Н. Потанина [Потанин 2007], А. В. Потаниной [Потанина 2003], Е. К. Яковлева [Яковлев 1900], Н. Ф. Катанова [Катанов 1903], Вс. Родевича [Родевич 2003], Д. Каррутерса [Каррутерс 2007], Г. Е. Грумм-Гржимайло [Грумм-Гржимайло 2007], Ф. Кона [Кон 1934], а также в отчетах археологических исследований М. Х. Маннай-оола [Маннай-оол 1961], А. Д. Грача [Грач 1980]. Эти ценные материалы, имеющие научное значение и в наше время, связаны с подлинно научным изучением Тувы как региона и языка, куль- 
туры, истории, этнографии ее народа в XX в., начало которому было положено в последние десятилетия XIX в.

Топонимия тувинского языка исследовалась учёными-тувиноведами: Ш. Ч. Сатом [Сат 1969], Б. И. Татаринцевым [Татаринцев 1973; Татаринцев 1977a; Татаринцев 1977б; Татаринцев 1993], М. В. Бавуу-Сюрюн [Бавуу-Сюрюн 2005; Бавуу-Сюрюн 2018], Н. Д. Сувандии [Сувандии 2013; Сувандии 2015], Л. С. Кара-оол [Кара-оол 2018; Кара-оол 2019]; и др.

Ведущее место в этом направлении занимают труды Б. К. Ондар, осветившей историю исследования топонимов Тувы и посвятившей данной проблеме ряд статей, две монографии [Ондар 2008а; Ондар 2008б], а также ею был составлен «Топонимический словарь Тувы», выдержавший два издания [Ондар 2004; Ондар 2007; Сувандии 2018].

Основной целью данной статьи является исследование топонимов, образованных с помощью числительных, которые специально не изучались, тогда как накоплены материалы, которые требуют систематизации и корректировки. Данные топонимы интересны тем, что на первый взгляд кажутся простыми, но при анализе вызывают сомнения, так как количественные показатели, заложенные в терминах, не всегда оправдываются географическими реалиями. И для выполнения поставленной цели были выдвинуты следующие задачи:

- уточнить значения числительных в составе топонимов, осуществить их систематизацию;

- уточнить первичность или вторичность возникновения топонимических метонимий [Олейникова 2016: 135-137];

- определить ареал распространения некоторых странствующих тюркских географических названий среди топонимов Тувы;

- определить происхождение компонентов сложных по составу топонимов с числительными.

Источниковую базу исследования составили полевые материалы автора, собранные во время комплексных или диалектологических экспедиций, также привлекались к анализу примеры, извлеченные из «Топонимического словаря Тувы» Б. К. Ондар [Ондар 2007].

\section{Основная часть}

Структурные и лексико-семантические особенности топонимов с числительными в тувинском языке

Топонимы с числительными, как и имена собственные из других групп ономастики, по своему составу могут быть производными и непроизводными. На материале нашего исследования мы выявили примеры только производных топонимов, образованных следующими способами:

1) конверсия: переход имен числительных в собственные существительные (субстантивация), например, чанцгыс 'один' $\rightarrow$ река Чаңзгыс, муң 'тысяча' $\rightarrow$ река Муң, правый приток реки Пий-Хема;

2) синтаксический способ. Значительная часть топонимов с числительными представлены сложными словами из двух и более основ; в качестве вторых компонентов выступают имена существительные и прилагательные и очень редко имена числительные, например, числ. + сущ.: Беш-Даг букв. 'пять гор', Тос-Терек букв. 'девять тополей'; числ. + прил.: Тос-Шанчыл букв. 'девять с выступами'; числ. + произв. прил.: Чеди-Баштыл букв. 'семь с вершинами (головами)'; числ. + прил. + сущ.: Беш-КараДылт букв. 'Пять черных лиственниц'; числ. + числ.: Тозан (тос он) букв. 'девятьсот (девять десять)’ и т. д. [Мурзаев 1996: 80-92; Кара-оол 2019: 368-369].

Количественные показатели в топонимах с числительными не всегда оправдываются географическими реалиями, поэтому мы сравнивали пояснения Б. К. Ондар в ее словаре с нашими данными (т. е. с тем, что нам говорили наши информанты или мы видели сами во время комплексных экспедиций), прежде чем сгруппировать топонимы по значению числительных в их составе. Если топоним оказывался странствующим тюркским географическим названием, зафиксированным на территории другого тюркоязычного региона, то для сравнения уточняли, какое пояснение дается авторами числительным [Койчубаев 1974; Молчанова 1979; Мурзаев 1996]. Таким образом, мы выделили следующие виды топонимов с числительными:

- топонимы, в которых количественный показатель точно определяет число географических объектов;

- топонимы, в которых количественный показатель передает значение 
'несколько';

- топонимы, в которых количественный показатель передает значение 'много';

- топонимы с неясным количественным показателем.

В качестве вторых компонентов топонимов с числительными часто выступают названия географических объектов даг 'гора', тей 'холм, сопка', а также деревьев - дыт 'лиственница', хадың 'береза', поэтому в ходе исследования мы сократили примеры с данными формантами.

1. Топонимы, в которых количественный показатель точно определяет число географических объектов

Э. М. Мурзаев отметил, что «малое количество географических объектов (гор, рек, близко текущих друг от друга, холмов, курганов и т. д.) легко обозримо и может быть четко охарактеризовано в самом названии» [Мурзаев 1996: 98]. Такие топонимы с числительными, действительно, не вызывают сомнения, так как в них количественные показатели совпадают с географическими реалиями, т. е. прямой характеристикой называемого объекта, что подтверждается следующими примерами:

Чаңгыс букв. 'один' - река в Эрзинском кожууне (районе) Республики Тыва. На территории с. Эрзин Чаңзгыс является единственной рекой [Ондар 2007: 159], собственно тувинское название: чаңугыс 'один' [ТРС 1968: 516].

Бир-Даг букв. 'одна гора' - гора в Бай-Тайгинском кожууне. Посреди равнины стоит единственная гора [Ондар 2007: 159], собственно тувинское название: бир 'один' [ТРС 1968: 104], даг 'гора' [ТРС 1968: 140].

Ийи-Мөгенниг-Даг букв. 'гора с двумя горбами' - топонимическая метонимия - это и гора, и урочшще, и стоянка на территории населенного пункта Баян-Кол в Кызылском кожууне. У горы две вершины, напоминающие горб верблюда [Ондар 2007: 215], собственно тувинское название: ийи 'два' [ТРС 1968: 203], мөген + ниг [мөъгениг] 'изобилующий горбами', дериват мөген 'горб' (у верблюда) [ТРС 1968: 300]. Первичным является название горы.

Ийи-Ортулук букв. 'два острова' - топонимическая метонимия - это местность и система реки Улуг-Хем в Улуг-Хемском кожууне [Ондар 2007: 215] собственно тувинское название: ийи 'два', ортулук [оъртулук] 'остров' [ТРС 1968: 327], дериват орту- 'середина' [Севортян 1974: 474], название местности вторично. В системе реки Енисей (Улуг-Хем) на территории Улуг-Хемского района РТ есть два острова, и вся местность вокруг них называется ИйиОртулук [ПМА 1999-2018].

Кош-Арга букв. 'парный лес' - местность в Тоджинском и Кызылском кожуунах. Название мотивировано тем, что леса, находящиеся на приграничной территории указанных кожуунов, как бы присоединились в горной местности [Ондар 2007: 254]: кош 'парный, двойной', 'сдвоенный' [ТРС 1968: 254], арга 'горный лес', 'бор' [ТРС 1968: 66]. Странствующее тюркское географическое название, зафиксированное в Горном Алтае (как урочище и населенный пункт Кош-Арка букв. 'небольшая гора с густым лесом' [Молчанова 1979: 228]; а также в форме Кош-Агач - как река и населенный пункт - Кош-Агачский район и одноименное село в Республике Алтай) и в Казахстане (как населенный пункт Кош-Aгач 'пара деревьев' [Мурзаев 1996: 95]).

Кош-Даг букв. 'пара гор' - гора в Тоджинском кожууне. В местности есть две соединенные горы [Ондар 2007: 254]: кош 'парный, двойной', 'сдвоенный' и даг 'гора' [ТувРС 1968: 140]. Странствующее тюркское географическое название, зафиксированное в Горном Алтае: река КошTyy (Koшта) букв. 'пара гор, возможно, сдвоенная, спаренная, соединенная гора или гора с двумя вершинами' [Молчанова 1979: 228].

Кош-Ой букв. 'парная низина' - река, левый приток реки Чаа-Хол в Чаа-Холском кожууне РТ. Река бежит по соединенной низине [Ондар 2007: 255; ПМА 1999-2018], собственно тувинское название: кош 'парный, двойной', ой 'низина', 'лощина' [ТРС 1968: 315].

Үи-Белдир букв. 'три перекрестка' топонимическая метонимия - курорт и минеральный источник в Каа-Хемском кожууне. Сероводородный минеральный источник появился на месте слияния трех рек - Шишхид-Гол, Бусин-Гол и Белин [Ондар 2007: 433], собственно тувинское название: $ү ш$ 'три' и белдир 'слияние', 'пе- 
рекресток, стык, распутье' [ТРС 1968: 98], первично название минерального источника.

Yu-Даш букв. 'три камня' - местность в Тоджинском кожууне. На местности лежат три больших камня [Ондар 2007: 433], собственно тувинское название: $y ш$ ‘три' и даш 'камень' [ТРС 1968: 149].

Үи-Дөргүн букв. 'три речки (берущие начало в степи и окруженные лесом)' местность в Монгун-Тайгинском кожууне. Местность названа по трем небольшим родникам, берущим начало в степи, окруженной лесом [Ондар 2007: 433; ПМА 1999 2018], собственно тувинское название: $y ш$ 'три' и дөргүн 'речка, берущая начало в степи, и окружающий ее лес' [ТРС 1968: 179].

Yu-Kaъm букв. 'три пласта' - гора в Пий-Хемском кожууне. Это безлесная трехскладчатая гора [Ондар 2007: 433; ПМА 1999-2018], собственно тувинское название: уш 'три' и каът 'ряд', 'слой, пласт', 'этаж', 'солнечная сторона отрога горного хребта (не покрытая лесом)' [ТРС 1968: 233].

Үи-Көжээ букв. 'три стелы' - местность в Пий-Хемском кожууне [ПМА 1999 2018]. У реки Биче-Баян-Кол есть местность Үш-Көжсээ: на холме стоят три каменные стелы, высотой около полутора метров. Согласно народной легенде, они были указателями дороги для воинов Чингис-хана. Эта местность - малая родина матери всемирно известной художницы Нади Рушевой [ПМА 1999-2018], собственно тувинское название: үш 'три' [ТРС 1968: 454], көжээ 'стела', 'балбал' [ТРС 1968: 257].

Үи-Мөөрүк букв. 'три куполообразные вершины горного хребта' - гора в Улуг-Хемском кожууне. Гора является одной из достопримечательностей Улуг-Хемского района: имеет три необычные вершины, похожие на купола [ПМА 1999-2018], собственно тувинское название: $y щ$ 'три' и мөөрүк 'куполообразная вершина горного хребта' [ТРС 1968: 302].

Үи-Өөш букв. 'три истока' - река, левый приток реки Бурен в Каа-Хемском кожууне. Три речки берут начало из одного места [Ондар 2007: 434], собственно тувинское название: $ү ш$ 'три' и өөш 'исток' [ТРС 1968: 338].

Үш-Хая букв. 'три скалы' - гора близ поселка Саглы в Овюрском кожууне. У пос. Саглы есть гора с тремя большими скалами
[Ондар 2007: 434], собственно тувинское название: уш 'три' и хая 'скала' [ТРС 1968: 471].

Дөрт-Хөл букв. 'четыре озера' - озеpo в Монгун-Тайгинском кожууне [Ондар 2007: 203]. На небольшой территории близко друг от друга находятся четыре озеpa [ПМА 1999-2018]: дөрm 'четыре' [ТРС 1968: 179] и хөл 'озеро' [ТРС 1968: 488]. Странствующее тюркское географическое название, зафиксированное в Ошской (Киргизия) и Карагандинской (Казахстан) областях как Торткол и в горах Тянь-Шаня — как Тӧрткол и Тӧрткул 'четыре озера' [Мурзаев 1996: 96].

Беш-Даг букв. 'пять гор' - топонимическая метонимия - гора и местность вблизи с. Сесерлиг в Пий-Хемском кожууне. На местности горная гряда, количественный показатель которой точно определил число объектов - гор [ПМА 1999-2018]: беш 'пять' [ТРС 1968: 100], даг 'гора' [ТРC 1968: 140]. Первично название горы. Странствующее тюркское географическое название, зафиксированное в Хакассии Пес таг и в Пятигорске Бештау [Успенский 1969].

Беш-Кожагар букв. 'пять пиков (высокие горы с острой вершиной)' - гора вблизи урочища Кулузун в Улуг-Хемском кожууне. Вереницей стоят пять гор с острыми вершинами [Ондар 2007: 156], собственно тувинское название: беш 'пять' и кожагар 'пик, высокая гора с острой вершиной', 'торчащий, высовывающийся' [ТРС 1968: 245].

Топонимы Тувы, в которых количественный показатель точно определяет число географических объектов, связаны с числительными от одного до пяти.

2. Топонимы, в которых количественный показатель передает значение 'несколько'

Относительность количественных показателей в тюркской топонимии подтверждается многими примерами из топонимических исследований [Молчанова 1979: $227-$ 228; Мурзаев 1996: 92-98]. Прежде всего, это связано с тем, что при больших количествах объектов зрительное их восприятие затрудняется и появляется представление о порядке величин: некоторое количество, много, очень много, необозримо много [Мурзаев 1996: 98]. 
В Пий-Хемском и Барун-Хемчикском районах Тувы есть река и местность Чаңгыс-Дыт букв. 'одна лиственница'. Но со временем, по данным наших информантов [ПМА 1999-2018], рядом выросли другие лиственницы, и количество деревьев увеличилось, а название сохранилось, как это часто бывает. И Чаңгыс-Дыт превратился в количественный топоним, семантика которого не соответствует денотату, а связано с другой формулировкой - несколько, какое -то малое число.

В топонимах Тувы с данным значением числительных в качестве второго компонента выступают названия деревьев. И, как видно из примеров, семантика числительных в данных топонимах, может быть, когда-то соответствовала слову, т. е. араты-кочевники, прибывшие в местность, назвали ее по отличительному признаку, но со временем деревьев стало больше, или вообще они высохли, а название сохранилось, т. е. в этих топонимах произошел смысловой сдвиг.

Ийи-Тал букв. 'две ивы (тальника) ' - топонимическая метонимия - это местность, гора и населенный пункт в Улуг-Хемском кожууне, в местности растут кустарниковые тальники [Ондар 2007: 215], собственно тувинское название: ийи 'два' и тал 'ива', 'тальник', 'лоза' [ТРС 1968: 404]. Первично название местности.

Үи-Дыттыг букв. 'с тремя лиственницами' - минеральный источник вблизи с. Сесерлиг в Пий-Хемском, Барун-Хемчикском кожуунах [Ондар 2007: 433]. У источника растут приметные лиственницы [ПМА 1999-2018], собственно тувинское название: үш 'три' [ТРС 1968: 454], дыттыс 'лиственничный' [ТРС 1968: 195].

Дөрт-Хадың букв. 'четыре березы' местность близ пос. Кызыл-Даг в Бай-Тайгинском кожууне. Местность получила название по приметным березам [Ондар 2007: 203], собственно тувинское название: $\partial ө p m$ 'четыре' [ТРС 1968: 179] и хадың̆ 'береза'.

Беш-Кара-Дыт букв. 'пять черных лиственниц' - топонимическая метонимия - местность, урочище и стоянка в Эрзинском кожууне. Местность получила название благодаря большим приметным лиственницам [Ондар 2007: 156], собственно тувинское название: беш 'пять' [ТРС 1968: 100], кара 'черный' [ТРС 1968: 226], дыт 'лиственница' [ТРС 1968: 195]. Пер- вично название местности. В Алтае есть гора и населенный пункт Беш-Tblm 'пять лиственниц' [Молчанова 1979: 157].

3. Топонимы, в которых количественный показатель передает значение 'много'

Значительная часть тувинских топонимов с относительным количественным показателем 'много, множество' выражена числительными, имеющими особое (в некоторых случаях сакральное) значение в тувинской культуре - чеди 'семь', тос 'девять', исключительное значение этих чисел подтверждается фразеологизмами и поговорками: чеди өкпези туруп кээр букв. 'семь легких [его, ее] встанут', т. е. сильно рассердится; чеди эртине 'семь драгоценностей'; чеди дер 'семь потов'; чеди адыр 'семь ветвей'; чеди кезектиг мөргүл 'молебен из семи частей'; чеди чүзун мал 'скот из девяти мастей'; Алды арга, чеди мегелиг '[У него] шесть хитростей и семь обманов'; башка букв. 'на все девять сторон', ср.: рус. 'на все четыре стороны'; тос каьт довурак алдынга кирзин букв. 'пусть попадет под девять слоев земли'; тос тостун соогу 'мороз девяти девять', т. е. лютый мороз; тос ура букв. 'девять хитростей', т. е. очень хитрый; тос эртине 'девять драгоценностей'; дортmaаш, тос хонар 'захотел прямиком, потерял девять дней’ и т. д.

Тюркологи ведут дискуссию о числительных «семь» и «девять». Например, С. К. Кенесбаев писал: «Значительное количество устойчивых сочетаний слов (идиомы, пословицы, поговорки и др.) группируются вокруг некоторых числительных: семь, три, девять, сорок - как вокруг своего рода „стержневых“ слов, что связано с древними верованиями и обрядами. В идиомах и других фразеологизмах они не имеют точного числового значения» [Кенесбаев 1954: 23]. Е. Койчубаев также считает стержневыми в тюркской топонимии числительные «семь», «девять», «сорок», «сто», «тысяча», которые указывают на неопределенное большое количество, на понятие «много» [Койчубаев 1974: 9]. Э. Мурзаев отметил, что в большинстве случаев такие количественные топонимы указывают на порядок величин: великое множество, обилие, некоторое число... [Мурзаев 1996: 93]. Такое значение имеет ряд топонимов Тувы: 
Чеди-Баштыг букв. 'семиголовый' гора в Сут-Хольском и Тандинском кожуунах, гора со множеством вершин [Ондар 2007: 484], собственно тувинское название: чеди 'семь' [ТРС 1968: 524], баш + тыг 'изобилующее вершинами (головами), 'с головой' [ТРС 1968: 96].

Чеди-Паш букв. 'семь котлов' - местность в степи по дороге на озеро Чедер. По легенде войска хана в степи оставили котлы [Ондар 2007: 484]; собственно тувинское название: чеди 'семь' [ТРС 1968: 524], nam 'чугунная чаша' [ТРC 1968: 345].

Чеди-Саң букв. 'семь обрядов окуривания (сжигая можжевельник)' - гора на хребте Чээнек в Улуг-Хемском кожууне. Священная гора, на которой постоянно совершают обряд окуривания, сжигая туркестанский можжевельник [Ондар 2007: 485; ПМА 1999-2018], собственно тувинское название: чеди 'семь' [ТРС 1968: 524], саң 'обряд окуривания' [ТРС 1968: 368].

Чеди-Тей букв. 'семь холмов' - река, впадающая в озеро Ак-Хол в Монгун-Тайгинском и Бай-Тайгинском кожуунах. В местности много сопок [Ондар 2007: 485; ПМА 1999-2018], собственно тувинское название: чеди 'семь' [ТРС 1968: 524], тей 'холм, сопка' [ТРС 1968: 410]. Первично название местности. В Казахстане зафиксирован топоним Жетикара букв. 'семь холмов' в значении 'много' и используется как название холма, населенного пункта и этнонима [Койчубаев 1974: 101].

Чеди-Хөл букв. 'семь озер' - наименование Чеди-Хольского района [Ондар 2007: 485]. На территории кожууна немало пресных и соленых озер [ПМА 1999-2018]. Странствующее тюркское географическое название, зафиксированное в Горном Алтае, как название реки, озера, горы Jeти-Кӧл 'семь озер' [Молчанова 1979: 182], в Казахстане озеро Жетиколь букв. 'семь озер' в значении 'много озер' [Койчубаев 1974: 101].

Toc-Apm букв. 'девять перевалов' - neревал на левом берегу Улуг-Хема [Ондар 2007: 393]. Между селами Баян-Кол Кызылского и Хадын Пий-Хемского районов немало перевалов, поэтому в данном топониме тос имеет значение 'много' [ПМА 19992018], собственно тувинское название: 'девять' [ТРС 1968: 417], арm 'перевал' [ТРС 1968: 69]. В Горном Алтае располо- жен перевал и населенный пункт Тогус-Ажу 'девять перевалов' [Молчанова 1979: 310].

Тос-Булак букв. 'девять источников' река, правый приток реки Бий-Хем в Тоджинском кожууне [Ондар 2007: 394]. Название указывает на множество родников в данной местности [ПМА 1999-2018]: тос 'девять' и булак 'исток', 'ручей' (в степи), 'родник' [ТувРС 1968: 121]. Тос-Булак, находящийся на территории Пий-Хемского района переименован в Кундустуг 'выдровый', но, как вспоминают старожилы, в этой местности никогда не водились выдры, как и сейчас [ПМА 1999-2018]. Странствующее тюркское географическое название, зафиксированное в Казахстане, как название $y p$. Токузбулак, слово токуз использовано в значении 'много' [Койчубаев 1974: 219].

Toc-Teйек букв. 'девять холмиков' топонимическая метонимия - речка и сопка вблизи Эйлиг-Хема. По многочисленным сопкам бегут ручейки [Ондар 2007: 394], собственно тувинское название: тос 'девять' и тей + ек 'холмик, сопочка' [ТРС 1968: 410]. Первичным является название сопок.

Toc-Tерек букв. 'девять тополей' местность вблизи села Аянгаты в Барун-Хемчикском кожууне. Местность названа по группе тополей, выросших на одном месте [Ондар 2007: 394], собственно тувинское название: тос 'девять' и терек 'тополь' [ТРС 1968: 412].

Он-Кум букв. 'десять песков' местность на склоне горы Хайыракан в Улуг-Хемском кожууне. Песчаная холмистая местность [Ондар 2007: 315], собственно тувинское название: он 'десять' [TPC 1968: 319] кум 'песок' [ТРС 1968: 264].

Он-Чылан букв. 'десять змей' - гора в Эрзинском кожууне РТ. На горе много змеиных гнезд и змей [Ондар 2007: 315], собственно тувинское название: $о н$ 'десять', чылан 'змея' [ТРС 1968: 555].

Он-Кажаа букв. 'десять оград (дворов)' - река, левый приток реки Элегест, урочище и стоянка в Тандинском кожууне). Название топонима связано с тем, что на берегу реки много загонов [Ондар 2007: 315], собственно тувинское название: $о н$ 'десять' [ТРС 1968: 319], кажаа 'двор, хлев', 'ограда, забор' [ТРС 1968: 217]. Первично название стоянки. 
Дөртен-Адыр букв. 'сорок развилок' топонимическая метонимия - это местность и урочище в Тоджинском кожууне. Местность названа так, скорее всего, из-за множества развилин [Ондар 2007: 203], собственно тувинское название: дөртен 'сорок' [ТРС 1968: 179], адыр 'развилина', 'ответвление', 'приток (реки)' [ТРС 1968: 38].

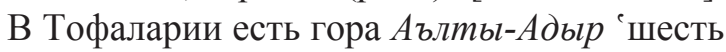
развилок' [Рассадин 2016:599].

Алдан-Маадыр букв. 'шестьдесят героев' - топонимическая метонимия - местность и населенный пункт в Сут-Хольском кожууне. Название связано с крупным протестом аратов против феодалов в 1889 г., который вошел в историю и как «Восстание 60 беглецов»; в период Тувинской Народной Республики стал известен как 'Восстание 60 богатырей' [Ондар 2007: 104]. На самом деле участников мятежа было намного больше, собственно тувинское название: алдан 'шестьдесят' [ТРС 1968: 54], маaдыр 'герой / героический', 'богатырь, витязь, батыр' [ТРС 1968: 284]. Первично название местности, где произошло восстание аратов.

Тозан букв. 'девяносто' - река, левыи приток реки Сыстыг-Хем в Тоджинском кожууне. Предположительно, река названа так из-за многочисленных притоков и разветвлений [Ондар 2007: 391], собственно тувинское название: тозан 'девяносто' [TPC 1968: 414].

Муң букв. 'тысяча' - река, правый приток реки Пий-Хем в Тоджинском кожууне. Река получила название из-за многочисленных притоков [Ондар 2007: 305; ПМА 1999-2018], собственно тувинское название: муң 'тысяча' [ТРС 1968: 303].

Сая-Нур букв. 'миллион озер' - топонимическая метонимия - местность и система реки Шамбалыг в Кызылском кожууне [Ондар 2007: 354], монгольское название: сая 'миллион' [ТРС 1968: 370], заимствование из тибетского посредством монгольского языка [Сухбаатар 1997: 168; БАМРС III: 101], нуур 'озеро', монголизм [БАМРС II: 429]. Разве можно посчитать миллион озер, поэтому в данном случае, несомненно, указывают на порядок величин — великое множество.

\section{4. Топонимы с неясным количествен-} ным показателем

В отдельных случаях неясно значение числительных в топонимах. Данные примеры могут вызвать дискуссию среди топонимистов, поэтому они требуют уточнения и более глубокого исследования.

Коши-Дыт букв. 'парная лиственница' - река, левый приток реки Кижи-Хем в Тоджинском кожууне [Ондар 2007: 254], собственно тувинское название: кош 'парный, двойной', дыт 'лиственница' [ТРС 1968: 195]. У истока реки стоят две лиственницы с одним корнем [ПМА 1999-2018], а в словаре Б. К. Ондар дается пояснение река названа по двум лиственницам в истоках [Ондар 2007: 254].

Кош-Пөш букв. 'парный кедр' - топонимическая метонимия - местность, река и система хребта Одуген в Тоджинском кожууне [Ондар 2007: 255], собственно тувинское название: кош 'парный, двойной', пөш 'кедр' [ТРС 1968: 350]. У реки растут два кедра с одним корнем [ПМА 1999-2018], в словаре Б. К. Ондар дается пояснение, что название дано по двум большим кедрам со спутанными ветвями в истоках [Ондар 2007: 255].

Беш-Белдир букв. 'пять перекрестков' - местность на территории пос. Торгалыг в Овюрском кожууне. Один информант дал сведения, что на местности много перекрестков дорог [ПМА 1999-2018], а другой информант сказал, что на местности пять перекрестков дорог [ПМА 1999-2018]: беш 'пять' [ТРС 1968: 100], белдир 'слияние', 'перекресток, стык, распутье' [ТувРС 1968: 98]. Странствующее тюркское географическое название, зафиксированное в Горном Алтае, как название реки и населенного пункта Беш-Белтир 'пять устьев' [Молчанова 1979: 156].

Сес-ЧYc букв. 'восемь суставов' или 'восемь сотен' - гора вблизи пос. Шамбалыг Кызылского кожууна. Название связывают с обилием зверья и богатой растительностью высокой горы [Ондар 2007: 358], наш информант данный топоним связывает с числительным сес чүс 'восемьсот' [ПМА 1999-2018], собственно тувинское название: сес 'восемь' [ТРС 1968: 374], чүс 'сустав' или чүс 'сто' [ТРС 1968: 552]. 
Tос-Шанчыг букв. 'девять выступов (гор)' - гора в Тес-Хемском кожууне. Гора имеет много выступов [Ондар 2007: 394], а наш информант пояснил, что гора имеет девять выступов [ПМА 1999-2018], собственно тувинское название: тос 'девять' и шанчыс 'с выступами' (горы) [ТРС 1968: 567].

Этимологические особенности компонентов топонимов с числительными

Как видно из рассмотренных выше топонимов, в качестве первого компонента выступают общетюркские числительные: бир 'один' [Севортян 1978: 146], чаңзысс 'один / одинокий' см. jayus 'один, единственный' [ДТС 1969: 235], ийи 'два', см. ики 'два' [Севортян 1974: 337-339], үш 'три', см. ${ }^{4}$ 'три' [Севортян 1974: 641], дөрт 'четыре', см. дө:pm 'четыре' [Севортян 1980: 284], беш 'пять', см. баш 'пять' [Севортян 1978: 126], алды 'шесть', см. алты 'шесть' [Севортян 1974: 141], чеди 'семь', см. йеди 'семь' [ЭСТЯ 1989: 167] сес 'восемь', см. секиз 'восемь' [ЭСТЯ 2003: 225] тос 'девять', докуз 'девять' [Севортян 1980: 255], он 'десять', см. о:н 'десять' [Севортян 1974: 455], дөртен 'сорок', алдан 'шестьдесят', тозан 'девяносто', сес чүс 'восемьсот' [Серебренников, Гаджиева 1979: 128], муңз 'тысяча' см. миңз 'тысяча' [ЭСТЯ 2003: 67], за исключением сая 'миллион', заимствованного из тибетского языка посредством монгольского [Сухбаатар 1997: 168; БАМРС III: 101].

Вторыми компонентами топонимов с числительными являются следующие названия:

1) общетюркские названия географических объектов: apm 'горный перевал' [Cевортян 1974: 179], ортулук [оъртулук] 'остров', дериват орту- см. общетюрк. орта 'середина' [Севортян 1974: 474; Татаринцев 2008: 341]; адыр 'развилина', 'ответвление' см. айыр [Севортян 1974: 114-116; Татаринцев 2000: 61]; арга [атрга] 'горный лес, бор', см. арка / арга 'север' [Севортян 1974: 174; Татаринцев 2000: 130]; орук 'дорога, путь', зафиксирован в тюркских языках Сибири [Татаринцев 2008: 342]; белдир [пэълдир] 'слияние', 'перекресток', др.-тюрк. белтир 'скрещение дорог, перекресток', 'место слияния рек' [ДТС 1969: 94] зафиксирован в тюркских языках Сибири, связывают с общетюрк. бел- 'талия', 'середина' [Татаринцев 2000: 210-211; Севортян 1978: 135]; бу- лак 'исток', 'ручей' (в степи), 'родник', см. булақ 'родник' [Севортян 1978: 257; Татаринцев 2000: 290]; даг 'гора', см. да:z 'гора' [Севортян 1980: 117-118]; дөргүн [төъргүн] 'речка, берущая начало в степи, и окружающий ее лес', общетюрское слово с узким ареалом распространения [Татаринцев 2002: 246-247]; каът 'ряд', 'слой, пласт', 'этаж' [ЭСТЯ 1997: 335; Татаринцев 2004: 128]; хая 'скала', слово представлено ещё в древнетюркских памятниках gaja 'скала' [ДТС 1969: 406]; хөл 'озеро' см. köl 'озеро' [ДТС 1969: 313], мөөрүк 'куполообразная вершина горного хребта' [Татаринцев 2008: 165];

2) общетюркские названия деревьев: дыт 'лиственница', отмечено ещё в древнетюркском (Махмуд Кашгари) tït - 'лиственница' [ДТС 1969: 569], распространено в тюркских языках Саяно-Алтая: см. алт., хак., шор., тоф. mыт 'лиственница' [Татаринцев 2002: 322-325]; тал 'ива', 'тальник', 'лоза', см. тал/дал 'ветвь, ветка' [Севортян 1980: 131]; терек 'тополь' общетюркское слово [ДТС 1969: 553; СИГТЯ 2001: 105, 134]; хадың 'береза', см. qајуy 'береза' [СИГТЯ 2001: 122; ЭСТЯ 1997: 213], пөш ‘кедр', см. тоф. бөш 'кедр', алт. мөш 'кедр' [Рассадин 1971: 165];

3) общетюркские названия других слов: кум 'песок', см. кум 'песок' [ЭСТЯ 2000: 133; Татаринцев 2004: 293]; өдек [өъдэк] слово зафиксировано и в других тюркских языках, тув. өдек 'навоз', 'окрестности жилья', скорее считается общетюркским [Татаринцев 2008: 359], имеются также монгольские соответствия, см. өтөг 'коровий, овечий навоз' и подобное [БАМРС III: 47]; nam [п'аш] 'чугунная чаша', зафиксировано в тюркских языках Сибири [Татаринцев 2008: 431]; чылан 'змея', см. йала:н 'змея' [ЭСТЯ 1989: 277];

4) монголизмы: кажаа [каъжа:] 'двор, хлев', 'ограда, забор', монголизм, см. хаша$a(н)$ 'забор', 'двор' и подобное [БАМРС IV: 73], слово зафиксировано в ряде тюркских языков [ЭСТЯ 1997: 346; Татаринцев 2004: 52]; көжээ [көъжэ:] 'каменная стела', монголизм [Татаринцев 2004: 234], см. монг. $x ө ш ө \theta(\mu)$ 'памятник' [БАМРС IV: 151]; монг. нуур 'озеро' [БАМРС II: 429]; сан 'обряд окуривания', монголизм, см. сан(2) 'ладан', 'воскурение фимиама' [БАМРС III: 84]; 
5) тюрко-монгольские слова: мөгенниг, дериват мөген [мөъгэн] 'горб' тюрко-монгольское слово, зафиксированное в тюркских языках Сибири [Татаринцев 2008: 153-154], имеет соответствие и в монгольском, см. бөх(өн) 'горб (у верблюда)' [БАМРC I: 277].

Таким образом, в географических названиях Тувы присутствуют следующие числительные: бир 'один', чаңдыс 'один / одинокий', ийи 'два', үш' 'три', дөрт 'четыре', беш 'пять', чеди 'семь', сес 'восемь', тос 'девять', он 'десять', дөртен 'сорок', алдан 'шестьдесят', тозан 'девяносто', мун 'тысяча', сая 'миллион', а также прил. кош 'парный' с количественным значением. Особо продуктивными являются топонимы с числительным $у ш$ 'три', чеди 'семь', тос 'девять'. Интересен тот факт, что в тувинском языке не зафиксирован ни один топоним с числительным алды 'шесть'.

Роль числительных в топонимах неоднозначна, так как не всегда можно их понимать буквально, на первый взгляд такие прозрачные имена, как, например, Ийи-Дьты 'две лиственницы', Дөрт-Хадың 'четыре березы', Чеди-Паш 'семь котлов', Тос-Аpm 'девять перевалов', Он-Чылан 'десять змей' и т. д., иногда имеют косвенное значение. Количественные показатели в топонимах могут определять точное число географических объектов или передавать значения 'несколько', 'много'.

В качестве первого компонента производных топонимов выступают в основном общетюркские числительные, а вторыми компонентами - общетюркские названия географических объектов, деревьев, а также незначительное число монголизмов или тюрко-монгольских слов, относящихся к другим лексическим группам слов, см. выше.

По топонимической метонимии можно заключить, что многие топонимы с числительными являются вторичными, т. е. населенные пункты, местности или стоянки именуются названиями рек, гор, урочищ, на которых находятся, или наоборот, как, например, названия местностей Чаңугыс-Дыт, Чеди-Тей или Кош-Пөш стали названиями рек Чаңұгыс-Дыт, Чеди-Тей, Кош-Пөш и т.д.
Выводы. В структурном и этимологическом отношениях значительную часть топонимов с числительными составляют собственно тувинские сложные слова. В качестве первого компонента сложных топонимов выступают общетюркские числительные, за исключением числительного сая 'миллион', которое заимствовано из тибетского посредством монгольского языка [Сухбаатар 1997: 168; БАМРС III: 101], а вторыми компонентами являются общетюркские названия географических объектов, деревьев, а также незначительное число монголизмов или тюрко-монгольских слов, относящихся к другим лексическим группам слов.

В топонимах с числительными количественный показатель может а) точно определить число географических объектов, б) передать значение 'несколько', в) передать значение 'много', но встречаются д) топонимы с неясным количественным показателем.

Среди топонимов Тувы с числительными зафиксировано несколько странствующих тюркских географических названий, ареалом распространения которых являются Горный Алтай, Казахстан, Киргизия, Хакасия и Кавказские Минеральные Воды: Кош-Арга — алт. Кош-Арка, каз. Кош-Агач, Кош-Даг - алт. Кош-Туу, Дөрт-Хөл - кир., каз. Торткол, Тӧрткол и Тӧрткул, Беш-Даг - хак. Пес таг, Бештау (Кавказские Минеральные Воды), Беш-КараДыт - алт. Беш-Тыт, Чеди-Хөл - алт. Јети-Кӧл, каз. Жетиколь, Тос-Арm - алт. Тогус-Ажу, Тос-Булак - каз. Токузбулак, Беш-Белдир - алт. Беш-Белтир.

Наличие в составе топонимов с числительными следующих формантов: гидронимических (хөл 'озеро'); фитонимических (дыıт 'лиственница', хадың 'береза', терек 'тополь', тал 'ива' ); оронимических (даг 'гора', тей 'холм, сопка', арт 'перевал', каът 'солнечная сторона отрога горного хребта'), а также дримонимических (арга 'лес') и т. д. указывают на природно-географические особенности Тувы.

Анализ показывает, что специфические особенности топонимов Тувы свойственны не только для данной территории, но и для топонимов тюркоязычных регионов Центральной и Средней Азии, Европей- 
ской части России, поэтому надеемся, что материал данной статьи будет полезен при изучении географических, этнокультурных и историко-культурных апеллятивов

\section{Полевой материал автора}

ПМА 1999-2018 - Полевые материалы автора с 1999 по 2018 гг.

\section{Author's Field Data}

Author's field data: 1999 to 2018. (In Tuv.)

Литература
Бавуу-Сюрюн $2005-$ Бавуу-Сюрюн M. B.

Структура топонимов монгольского происхождения на территории Тувы // Тыва дылдың лексиказынга факультативтер / научн. ред. Е. Б. Салзынмаа. Кызыл: Аныяк, 2005. C. 111-115.

Бавуу-Сюрюн 2018 - Бавуу-Сюрюн М. В. Топонимы как маркеры диалектов и говоров тувинского языка [электронный ресурс] // Новые исследования Тувы. № 3. URL: https://nit.tuva.asia/nit/article/view/786 DOI: 10.25178/nit.2018.3.2 (дата обращения: 19.07.2019).

БАМРС I - Большой академический монгольско-русский словарь. В 4-х т. Т. І. А - Г/ отв. ред. Г. Ц. Пюрбеев. М.: Academia, 2001. $488 \mathrm{c}$.

БАМРС II - Большой академический монгольско-русский словарь. В 4-х т. Т. ІІ. Д - О / отв. ред. Г. Ц. Пюрбеев. М.: Academia, 2001. $514 \mathrm{c}$.

БАМРС III - Большой академический монгольско-русский словарь. В 4-х т. Т. ІІІ. Ө-Ф/ отв. ред. Г. Ц. Пюрбеев. М.: Academia, 2001. $440 \mathrm{c}$.

БАМРC IV - Большой академический монгольско-русский словарь. В 4-х т. Т. IV. Х - Я / отв. ред. Г. Ц. Пюрбеев. М.: Academia, 2002. $510 \mathrm{c}$.

Веселков $1871-$ Веселков Н. Ф. Урянхи и географические сведения о южной границе Минусинского округа // Известия ИРГО. 1871. T. VII. Вып. 2. С. 113-118.

Грач 1980 - Грач А. Д. Древние кочевники в центре Азии. М.: Наука, 1980. 256 с.

Грумм-Гржимайло 2007 - Грумм-Гржимайло $\Gamma$. E. Западная Монголия и Урянхайский край. Антропологический и этнографический очерк этих стран // Урянхай. Тыва деп- в топонимии, а также будут использованы при исследовании ареала распространения странствующих тюркских географических названий.

тер. Антология научной и просветительской мысли о древней тувинской земле и ее насельниках, об Урянхае-Танну-Туве, урянхайцах-тувинцах, о древностях Тувы: в 7 т. / сост. С. К. Шойгу. М.: Слово, 2007. Т. 2. Племена Саяно-Алтая. Урянхайцы (IV в. начало ХХ в.). С. 496-638.

ДТС 1969 - Древнетюркский словарь. Л.: Наука, 1969.676 с.

Кара-оол 2018 - Кара-оол Л. С. Лексические особенности топонимов Овюрского района Тувы [электронный ресурс] // Новые исследования Тувы. 2018, № 3. URL: https://nit. tuva.asia/nit/article/view/795 (дата обращения: 15.05.2019). DOI: 10.25178/nit.2018.3.11 224

Кара-оол 2019 - Кара-оол Л. С. Лексика родильных обрядов в топонимах Тувы // Мир науки, культуры, образования. 2019. Вып. 3 (76). С. 368-369.

Каррутерс 2007 - Каррутерс Д. Неведомая Монголия. Урянхайский край. Т. 1. / пер. с англ. Н. В. Турчанинова. Петроград // Урянхай. Тыва дептер. Антология научной и просветительской мысли о древней тувинской земле и ее насельниках, об Урянхае-Танну-Туве, урянхайцах-тувинцах, о древностях Тувы: в 7 т. / сост. С. К. Шойгу. Т. 4. Урянхайский край: перекресток мнений (конец XIX - начало XX вв.). М.: Слово, 2007. C. $10-260$.

Катанов 1903 - Катанов Н. Ф. Опытъ изслъдованія урянхайскаго языка, съ указаніемъ главньйшихъ родственныхъ отношеній его къ другимъ языкамъ тюркскаго корня. Казань: Типо-литографія Императорскаго Казанскаго Университета, 1903. 1600 с.

Кенесбаев 1954 - Кенесбаев А. Е. О некоторых особенностях фразеологических единиц в казахском языке // Известия АН КазССР. 1954. № 135. Серия филологии и искусствоведения. Вып. 1 - 2. С. 6-27.

Койчубаев 1974 - Койчубаев E. Краткий толковый словарь топонимов Казахстана. Алма-Ата: Наука, 1974. 275 с.

Кон 1934 - Кон Ф. Я. За пятьдесят лет. Собрание сочинений в 3 т. Т. 3. Экспедиция в 
Сойотию. М.: изд-во Всесоюз. о-ва политкаторжан и ссыльно-поселенцев; тип. Профиздата, 1934. 293 с.

Кормушин 1997 - Кормушин И. В. Тюркские енисейские эпитафии. Тексты и исследования / отв. ред. Э. Р. Тенишев. М.: Наука, 1997. $303 \mathrm{c}$.

Кормушин $2008-$ Кормушин И. В. Тюркские енисейские эпитафии. Грамматика, текстология / отв. ред. Д. М. Насилов. М.: Наука, 2008. 342 c.

Маннай-оол 1961 - Маннай-оол М. Археологические исследования в Овюрском районе в 1960 г. // Ученые записки ТНИИЯЛИ. Вып. IX. / ред. коллегия: Сердобов Н. А. и др. Кызыл: Тип-я Управления культуры, 1961. С. 222-229.

Молчанова 1979 - Молчанова О. Т. Топонимический словарь Горного Алтая. Горно-Алтайск: Алтайск. кн. изд-во, 1979. 378 с.

Мурзаев 1996 - Мурзаев Э. М. Тюркские географические названия. М.: Вост. лит., 1996. $254 \mathrm{c}$.

Олейникова 2016 - Олейникова С. Д. Метонимические переносы в топонимии (на материале ойконимов Тамбовской области) // Филологические науки. Вопросы теории и практики. Тамбов: Грамота, 2016. № 6 (60): в 3-х ч. Ч. 2. С. 135-137.

Ондар 2004 - Ондар Б. К. Топонимический словарь Тувы. Абакан: Изд-во ХГУ им. Н. Ф. Катанова, 2004. 254 с.

Ондар 2007 - Ондар Б. К. Топонимический словарь Тувы. 2-е изд. Кызыл: Тувинское кн. изд-во, 2007. 550 с.

Ондар 2008а - Ондар Б. К. Тувинская топонимия. Сопоставительный анализ топонимии Тувы с топонимией Южной Сибири и других тюркоязычных территорий. Кызыл: Тувинск. кн. изд-во, 2008. 304 с.

Ондар $2008 б-$ Ондар Б. К. Тувинская топонимика: проблемы, поиски, решения. Проблемы преподавания русского языка в вузе и в школе. Кызыл: РИО ТувГУ, 2008. 233 с.

Потанин 2007 - Потанин Г. Н. Очерки Северо-Западной Монголии. Результаты путешествия, исполненного в 1876-1877 годах по поручению Императорского Русского Географического Общества. Выпуск II. Материалы этнографические. СПб. // Урянхай. Тыва дептер. Антология научной и просветительской мысли о древней тувинской земле и ее насельниках, об Урянхае-Танну-Туве, урянхайцах-тувинцах, о древностях Тувы: в 7 т. / сост. С. К. Шойгу. Т. 2. Племена Саяно-Алтая. Урянхайцы (IV в. - начало XX в.). М.: Слово, 2007. С. 374-495.

Потанина 2003 - Потанина А. В. Из путешествий по Восточной Сибири, Монголии, Тибету и Китаю. Из странствий по Урянхайской земле // Традиционная культура тувинцев глазами иностранцев (конец XIX начало XX вв.) / подгот. текстов, предисл. и коммент. А. К. Кужугет. Кызыл: Тувинское кн. изд-во, 2003. С. 29-38.

Рассадин 1971 - Рассадин В. И. Фонетика и лексика тофаларского языка. Улан-Удэ: Бурятск. кн. изд-во, 1971. 252 с.

Рассадин 2016 - Рассадин В. И. Тофаларско-русский словарь. М.: ИД «ЯСК», 2016. $608 \mathrm{c}$.

Родевич 2003 - Родевич Bc. Урянхайский край и его обитатели. Санкт-Петербург // Традиционная культура тувинцев глазами иностранцев (конец XIX — начало XX вв.) / подгот. текстов, предисл. и коммент. А. К. Кужугет. Кызыл: Тувинск. кн. изд-во, 2003. C. 136-141.

Сат 1969 - Сат Ш. Ч. Заметки по топонимии Тувы // Мат-лы конф. «Этногенез народов Северной Азии» / отв. ред. Е. И. Убрятова. Вып. 1. Новосибирск, 1969. С. 232-234.

Севортян 1974 - Севортян Э. В. Этимологический словарь тюркских языков: общетюркские и межтюркские основы на гласные. М.: Наука, 1974. 768 с.

Севортян 1978 - Севортян Э. В. Этимологический словарь тюркских языков: общетюркские и межтюркские основы на буквы “Б”. М.: Наука, 1978. 352 с.

Севортян $1980-$ Севортян Э. В. Этимологический словарь тюркских языков: общетюркские и межтюркские основы на буквы “В”, “Г”, “Д”. М.: Наука, 1980. 396 с.

Серебренников, Гаджиева 1979 - Серебренников Б. А., Гаджиева Н. 3. Сравнительно-историческая грамматика тюркских языков. Баку: МААРИФ, 1979. 304 с.

СИГТЯ 2001 - Сравнительно-историческая грамматика тюркских языков. Лексика / отв. ред. Э. Р. Тенишев М.: Наука, 2001. 822 с.

Сувандии $2013-$ Сувандии Н. Д. Современное состояние изучения ономастики тувинского языка // Мир науки, культуры, образования. Вып. 6 (43). 2013. С. 362-364.

Сувандии 2015 - Сувандии Н. Д. Становление фамилий и отчеств в тувинском языке // Филологические науки. Вопросы теории и практики. № 12 (54). Ч. I. 2015. С. 171-173. 
Сувандии 2018 - Сувандии Н. Д. Вклад Бичен Кыргысовны Ондар в развитие топонимики Тувы [электронный ресурс] // Новые исследования Тувы. № 3. URL: https://nit. tuva.asia/nit/article/view/785 DOI: 10.25178/ nit.2018.3.1 (дата обращения: 19.07.2019).

Сухбаатар 1997 - Сухбаатар О. Монгол хэлний харь угийн толь (=перевод на рус.яз.) Улаанбаатар: Адмон пресс, 1997. 234 с.

Татаринцев 1973 - Татаринцеев Б. И. Об особенностях топонимии Северо-Восточной Тувы // Происхождение аборигенов Сибири и их языков: Мат-лы всесоюз. конф. 1416 июня 1973 г. / ред. коллегия: Э. Г. Беккер [и др.]. Томск: Изд-во Томского университета, 1973. С. 142-144.

Татаринцев 1977 a - Татаринцеев Б. И. Местные географические термины Северо-Восточной Тувы // Советская тюркология / гл. ред. М. Ш. Ширалиев. Баку: Тип-я им. 26 бакинских комиссаров, 1977. Вып. 5. С. 18-26.

Татаринцев 19776 - Татаринцев Б. И. О топонимии бассейна р. Каа-Хем // Тувинский язык и литература в послеоктябрьский период / ред. коллегия: Д. А. Монгуш (отв. ред.) [и др.]. Кызыл: Тип-я управления по делам издательств, полиграфии и книжной торговли Совета Министров Тув. АССР, 1977. C. $88-98$.

Татаринцев 1993 - Татаринцев Б. И. О некоторых древних топонимах тюркского происхождения на территории Тувы // Вопросы тувинского языкознания / ред. Д. А. Монгуш, Б. И. Татаринцев. Кызыл: Новости Тувы, 1993. С. 105-113.

Татаринцев 2000 - Татаринщев Б. И. Этимологический словарь тувинского языка. Новосибирск: Наука, 2000. Т. І. А - Б. 341 с.

Татаринцев 2002 - Татаринцев Б. И. Этимологический словарь тувинского языка. Новосибирск: Наука, 2002. Т. ІІ. Д - Й. 388c.

Татаринцев 2004 - Татаринцев Б. И. Этимологический словарь тувинского языка. Новосибирск: Наука, 2004. Т. III. К - Л. 440 с.

Татаринцев 2008 - Татаринцев Б. И. Этимологический словарь тувинского языка. Новосибирск: Наука, 2004. T. IV. М - П. 442 с.

ТРС 1968 - Тувинско-русский словарь: 22000 слов / ред. Тенишев Э. Р. М.: Сов. энц., 1968. $648 \mathrm{c}$.

Успенский $1969-$ Успенский Л. В. Загадки топонимики. М.: Молодая гвардия. 1969. 267 с.

Шварц 1864 - Амур, река (бассейн). Карта речных областей Амура, южной части Лены и
Енисея, и острова Сахалин ... [Карты] / сост. на основании изысканий Сибирской экспедиции ... Рус. Геогр. общества Глав. астрономом экспедиции Людвигом Шварцом. СПб.: Ильин, 1864. (7 л.: цв., раскраска от руки).

ЭСТЯ 1989 - Этимологический словарь тюркских языков: общетюркские и межтюркские основы на буквы “Ж,”, “Ж”, “Й” / отв. ред. Л. С. Левитская. М.: Наука, 1989. $293 \mathrm{c}$.

ЭСТЯ 1997 - Этимологический словарь тюркских языков: общетюркские и межтюркские основы на букву “К”, “К”. Вып. 1 / отв. ред. Г. Ф. Благова. М.: Языки русской культуры, 1997. 368 с.

ЭСТЯ 2000 - Этимологический словарь тюркских языков: общетюркские и межтюркские основы на букву “К”. Вып. 2 / отв. ред. Г. Ф. Благова. М.: Индрик, 2000. $265 \mathrm{c}$.

ЭСТЯ 2003 - Этимологический словарь тюркских языков: общетюркские и межтюркские лексические основы на буквы “Л”, “М”, “Н”, “П”, “С” / отв. ред. А. В. Дыбо. М.: Вост. лит., 2003. 446 с.

Яковлев 1900 - Яковлев Е. К. Этнографический обзор инороднего населения долины Южного Енисея и объяснительный каталог этнографического отдела музея. Выпуск 4. Минусинск: Типография В. И. Корнакова, 1900. 214 c.

\section{References}

[A Comparative Historical Grammar of Turkic Languages: Vocabulary]. E. R. Tenishev (ed.). Moscow: Nauka, 2001. 824 p. (In Russ.)

[A Dictionary of Old Turkic]. V. M. Nadelyaev et al. (eds.). Leningrad: Nauka, 1969. 676 p. (In Russ.)

[An Etymological Dictionary of Turkic Languages: Common Turkic and Inter-Turkic Stems with the Initial Letters 'Ж,', 'Ж', 'Й']. L. S. Levitskaya (ed.). Moscow: Nauka, 1989. 293 p. (In Russ.)

[An Etymological Dictionary of Turkic Languages: Common Turkic and Inter-Turkic Stems with the Initial Letters ' $K$ ', 'K']. Is. 1. G. F. Blagova (ed.). Moscow: Yazyki Russkoy Kul’tury, 1997. 368 p. (In Russ.)

[An Etymological Dictionary of Turkic Languages: Common Turkic and Inter-Turkic Stems with the Initial Letter ' $K$ ']. Is. 2. G. F. Blagova (ed.). Moscow: Indrik, 2000. 265 p. (In Russ.) 
[An Etymological Dictionary of Turkic Languages: Common Turkic and Inter-Turkic Stems with the Initial Letters 'Л', 'M', 'H', ' $\Pi$ ', 'C']. A. V. Dybo (ed.). Moscow: Vost. Lit., 2003. 448 p. (In Russ.)

[The Unabridged Academic Mongolian-Russian Dictionary]. In 4 vols. Vol. I: A $-\Gamma$. G. Ts. Pyurbeev (ed.). Moscow: Academia, 2001. 488 p. (In Russ. and Mong.)

[The Unabridged Academic Mongolian-Russian Dictionary]. In 4 vols. Vol. II: Д - O. G. Ts. Pyurbeev (ed.). Moscow: Academia, 2001. 514 p. (In Russ. and Mong.)

[The Unabridged Academic Mongolian-Russian Dictionary]. In 4 vols. Vol. III: $\Theta-\Phi$. G. Ts Pyurbeev (ed.). Moscow: Academia, 2001. 440 p. (In Russ. and Mong.)

[The Unabridged Academic Mongolian-Russian Dictionary]. In 4 vols. Vol. IV: X - Я. G. Ts. Pyurbeev (ed.). Moscow: Academia, 2002. 510 p. (In Russ. and Mong.)

[Tuvan-Russian Dictionary: 20000 Entries]. E. R. Tenishev (ed.). Moscow: Sovetskaya Entsiklopediya, 1968. 648 p. (In Tuv. and Russ.)

[The Amur River (Basin): a Map of River Areas of the Amur, Southern Part of the Lena and Yenisei, ans Sakhalin Island ... ]. Maps by Ludwig Schwartz summarizing the investigations of the Siberian Expedition of the Russian Geographical Society. St. Petersburg: Ilyin, 1864. 7 p. (In Russ.)

Bavuu-Surun M. V. Place names as markers of the dialects and sub-dialects of Tuvan language. The New Research of Tuva. 2018. No. 3. An Internet resource: https://nit.tuva.asia/nit/ article/view/786 DOI: 10.25178/nit.2018.3.2 (accessed: July 19, 2019). (In Russ.)

Bavuu-Syuryun M. V. Toponyms of Mongolian origin in the territory of Tuva: lexical structures revisited. In: [Optional Courses: Tuvan Vocabulary]. E. B. Salzynmaa (ed.). Kyzyl: Anyyak, 2005. Pp. 111-115. (In Russ.)

Carruthers D. Unknown Mongolia. The Uriankhai Country. Vol. 1. (transl. by N. V. Turchaninov, St. Petersburg). In: [Uriankhai. Tyva Depter: an Anthology of Scientific and Educational Thought about the Ancient Land of Tuva and Its Heirs, about Uriankhai - Tannu-Tuva, the Uriankhai People - Tuvans, and Tuva's Antiquities]. In 7 vols. S. K. Shoygu (comp.). Moscow: Slovo, 2007. Vol. 4: The Uriankhai Country - a Crossroads of Opinions (late $19^{\text {th }}$ to early $20^{\text {th }}$ cc.). Pp. 10-260. (In Russ.)
Grach A. D. [Ancient Nomads in the Center of Asia]. Moscow: Nauka, 1980. 256 p. (In Russ.) Grumm-Grzhimailo G. E. Western Mongolia and the Uriankhai Country: an anthropological and ethnographic essay of the lands. In: [Uriankhai. Tyva Depter: an Anthology of Scientific and Educational Thought about the Ancient Land of Tuva and Its Heirs, about Uriankhai - TannuTuva, the Uriankhai People - Tuvans, and Tuva's Antiquities]. In 7 vols. S. K. Shoygu (comp.). Moscow: Slovo, 2007. Vol. 2: Tribes of the Sayan Altai. The Uriankhais ( $4^{\text {th }}$ to early $20^{\text {th }}$ cc.). Pp. 496-638. (In Russ.)

Kara-ool L. S. Lexical features of the microtoponyms of Ovyur Rayon of Tuva. The New Research of Tuva. 2018. No. 3. An Internet resource: https:// nit.tuva. asia/nit/article/view/795 (accessed: May 15, 2019). DOI: 10.25178/nit.2018.3.11 224 (In Russ.)

Kara-ool L. S. Lexicon of maternity-related rites in toponyms of Tuva. The World of Science, Culture and Education. 2019. Vol. 3 (76). Pp. 368-369. (In Russ.)

Katanov N. F. [A Research Essay on the Uriankhai Language with Indication of Its Key Essential Ties to Other Turkic Languages]. Kazan: Imper. Kazan Univ., 1903. 1600 p. (In Russ.)

Kenesbaev A. E. Kazakh phraseological units: some peculiarities revisited. Izvestiya AN KazSSR. 1954. No. 135. Ser. 'Philology and Art Studies'. Is. 1 - 2. Pp. 6-27. (In Russ.)

Koichubaev E. [Toponyms of Kazakhstan: a Concise Dictionary]. Alma-Ata: Nauka, 1974. 275 p. (In Russ.)

Kon F. Ya. [Over the Fifty Years: Collected Works]. In 3 vols. Moscow: All-Russia Society of PreRevolutionary Political Convicts and Deportees (Profizdat), 1934. 293 p. Vol. 3: The Expedition to Soyotia. (In Russ.)

Kormushin I. V. [Turkic Epitaphs of the Yenisei: Grammar and Textology]. by D. M. Nasilov (ed.). Moscow: Nauka, 2008. 342 p. (In Russ.)

Kormushin I. V. [Turkic Epitaphs of the Yenisei: Texts and Studies]. E. R. Tenishev (ed.). Moscow: Nauka, 1997. 303 p. (In Russ.)

Mannai-ool M. Kh. Archaeological surveys in Ovyursky District: 1960. In: [Scholarly Notes of the Tuvan Research Institute of Language, Literature and History. Is. IX]. N. A. Serdobov et al. (eds.). Kyzyl: Dept. of Culture, 1961. Pp. 222-229. (In Russ.)

Molchanova O. T. [The Altai Mountains: a Toponymic Dictionary]. Gorno-Altaysk: Altaian Book Publ., 1979. 378 p. (In Russ.) 
Murzaev E. M. [Turkic Geographical Names]. Moscow: Vost. Lit., 1996. 254 p. (In Russ.)

Oleinikova S. D. Metonymic tropes in toponymy (by the material of place names of Tambov Region). Philological Sciences. Issues of Theory and Practice. Tambov: Gramota, 2016. No. 6 (60): in 3 parts. Part 2. Pp. 135-137. (In Russ.)

Ondar B. K. [The Toponymic Dictionary of Tuva]. $2^{\text {nd }}$ ed. Kyzyl: Tuv. Book Publ., 2007. 550 p. (In Russ.)

Ondar B. K. [The Toponymic Dictionary of Tuva]. Abakan: Khakas State Univ., 2004. 254 p. (In Russ.)

Ondar B. K. [Tuvan Toponymy. Toponymy of Tuva, Southern Siberia and Other TurkicInhabited Territories: a Comparative Analysis]. Kyzyl: Tuv. Book Publ., 2007. 304 p. (In Russ.)

Ondar B. K. [Tuvan Toponymy: Problems, Investigations, Solutions. Russian Language Teaching Problems: University and School Levels]. Kyzyl: Tuv. State Univ., 2008. 233 p. (In Russ.)

Potanin G. N. Essays on Northwestern Mongolia: Summarizing Results of the 1876-1877 Journey Undertaken on Instructions from the Imperial Russian Geographical Society. Vol. II: Ethnographic Materials. (St. Petersburg). In: [Uriankhai. Tyva Depter: an Anthology of Scientific and Educational Thought about the Ancient Land of Tuva and Its Heirs, about Uriankhai - Tannu-Tuva, the Uriankhai People - Tuvans, and Tuva's Antiquities]. In 7 vols. S. K. Shoygu (comp.). Moscow: Slovo, 2007. Vol. 2: Tribes of the Sayan Altai. The Uriankhais ( $4^{\text {th }}$ to early $20^{\text {th }}$ cc.). Pp. $374-495$. (In Russ.)

Potanina A. V. Glimpses of travels across Eastern Siberia, Mongolia, Tibet and China. Episodes describing wanderings in the Uriankhai lands. In: [Tuvan Traditional Culture in the Eyes of Foreigners (Late $19^{\text {th }}-$ Early 20 $0^{\text {th }} \mathrm{cc}$.)]. A. K. Kuzhuget (comp.). Kyzyl: Tuv. Book Publ., 2003. Pp. 29-38. (In Russ.)

Rassadin V. I. [The Tofalar Language: Phonetics and Vocabulary]. Ulan-Ude: Buryat Book Publ., 1971. 252 p. (In Russ.)

Rassadin V. I. [Tofalar-Russian Dictionary]. Moscow: YaSK, 2016. 608 p. (In Russ. and Tof.)

Rodevich V. The Uriankhai Country and its inhabitants. In: [Tuvan Traditional Culture in the Eyes of Foreigners (Late 19 ${ }^{\text {th }}$ - Early $20^{\text {th }}$ cc.)]. A. K. Kuzhuget (comp.). Kyzyl: Tuv.
Book Publ., 2003. Pp. 136-141. (In Russ.)

Sat Sh. Ch. Notes on the toponymy of Tuva. In: [Ethnogenesis of North Eurasian Peoples]. Conf. proc. E. I. Ubryatova (ed.). Novosibirsk, 1969. Pp. 232-234. (In Russ.)

Serebrennikov B. A., Gadzhieva N. Z. [A Comparative Historical Grammar of Turkic Languages]. Baku: MAARIF, 1979. 304 p. (In Russ.)

Sevortyan E. V. [An Etymological Dictionary of Turkic Languages: Common Turkic and InterTurkic Stems with the Initial Letter 'B']. N. Z. Gadzhieva (ed.). Moscow: Nauka, 1978. 352 p. (In Russ.)

Sevortyan E. V. [An Etymological Dictionary of Turkic Languages: Common Turkic and InterTurkic Vowel Stems]. R. M. Zaleskovskaya (ed.). Moscow: Nauka, 1974. 768 p. (In Russ.)

Sevortyan E. V. [An Etymological Dictionary of Turkic Languages: Common Turkic and InterTurkic Stems with the Initial Letters 'V', 'G', 'D']. N. Z. Gadzhieva (ed.). Moscow: Nauka, 1980. 396 p. (In Russ.)

Sukhbaatar O. [A Dictionary of Loanwords in Mongolian]. Ulaanbaatar: Admon Press, 1997. 234 p. (In Mong.)

Suvandii N. D. Bichen Kyrgyzovna Ondar and her contribution to the study of the toponymy of Tuva. The New Research of Tuva. No. 3. An Internet resource: https:/nit.tuva.asia/nit/ article/view/785 DOI: 10.25178/nit.2018.3.1 (accessed: July 19, 2019). (In Russ.)

Suvandii N. D. The formation of surnames and patronymic names in the Tuvinian language. Philological Sciences. Issues of Theory and Practice. 2015. No. 12 (54). Part I. Pp. 171173. (In Russ.)

Suvandii N. D. Tuvan onomastics: the current stage of research. The World of Culture, Science and Education. 2013. Vol. 6 (43). Pp. 362-364. (In Russ.)

Tatarintsev B. I. [An Etymological Dictionary of the Tuvan Language]. Vol. I: A-Б. Novosibirsk: Nauka, 2000. 341 p. (In Russ. and Tuv.)

Tatarintsev B. I. [An Etymological Dictionary of the Tuvan Language]. Vol. II: Д-Й. Novosibirsk: Nauka, 2002. 388 p. (In Russ. and Tuv.)

Tatarintsev B. I. [An Etymological Dictionary of the Tuvan Language]. Vol. III: К-Л. Novosibirsk: Nauka, 2004. 440 p. (In Russ. and Tuv.)

Tatarintsev B. I. [An Etymological Dictionary of the Tuvan Language]. Vol. IV: M-П. Novosibirsk: Nauka, 2004. 442 p. (In Russ. and Tuv.) 
Tatarintsev B. I. Local geographical terms of the Northeastern Tuva. Sovetskaya tyurkologiya. 1977. No. 5. Pp. 18-26. (In Russ.)

Tatarintsev B. I. Northeastern Tuva: peculiarities of toponymy revisited. In: [Origins of Siberia's Native Populations and Their Languages]. Conf. proc. (June 14-16, 1973). E. G. Becker et al. (ed.). Tomsk: Tomsk State Univ., 1973. Pp. 142-144. (In Russ.)

Tatarintsev B. I. Revisiting some old toponyms of Turkic origin in the territory of Tuva. In: [Questions of Tuvan Linguistics]. D. A. Mongush, B. I. Tatarintsev (eds.). Kyzyl: Novosti Tuvy, 1993. Pp. 105-113. (In Russ.)

Tatarintsev B. I. The toponymy of the Kaa-Khem River basin revisited. In: [The Tuvan Language and Literature in the Post-October Era]. Kyzyl: Publ. and Book Retail Dept. (Council of Ministers of the Tuvan ASSR), 1977. Pp. 88-98. (In Russ.)

Uspensky L. V. [Riddles of Toponymy]. Moscow: Molodaya Gvardiya, 1969. 267 p. (In Russ.)

Veselkov N. F. The Uriankhais and geographical information about the southern boundary of Minusinsky Okrug. Izvestiya IRGO. 1871. Vol. VII. Is. 2. Pp. 113-118. (In Russ.)

Yakovlev E. K. [An Ethnographic Review of the Non-Russian Population of the Southern Yenisei Valley, Supplemented with an Explanatory Catalog of the Museum's Ethnographic Department]. Vol. 4. Minusinsk: V. I. Kornakov, 1900. 214 p. (In Russ.) 